\title{
Pertanggungjawaban Pidana Oknum Syahbandar dalam Tindak Pidana Penyalahgunaan Wewenang di bidang Pelayaran
}

\author{
Criminal Responsibility of Syahbandar Persons in Crime of Abuse of \\ Authority in the Field of Shipping
}

\author{
Aldin \\ Universitas Halu Oleo \\ E-mail: Aldin2427@gmail.com \\ Oheo K. Haris \\ Pascasarjana Universitas Halu Oleo \\ E-mail: oheokh@gmail.com \\ Sabrina Hidayat \\ Pascasarjana Universitas Halu Oleo \\ E-mail: sabrina.hidayat54@yahoo.com
}

\begin{abstract}
This study aims: 1. To find out and analyze the qualifications of criminal acts of abuse of authority in the field of shipping carried out by individuals who can be requested for criminal responsibility; 2. To find out and analyze the criminal liability of individual martyrdom officers in criminal acts of abuse of authority in the field of shipping.

The type of research that I use in research is normative or doctrinal research. The legal material collection technique that supports and is related to the presentation of this research is the study of documents (library studies).

The results of the study show that: 1. In case Number 37/Pid.Sus/202/PN.Smp, the defendant Mihtafol Arifin issued a sailing letter to the KL Sum Sinar Sumekar vessel which was not equipped with documents on the seaworthiness of the vessel as referred to in Article 117 Paragraph (2) of Law Number 17 In 2008 concerning Shipping, it was also not equipped with communication equipment as referred to in Article 131 Paragraph (2) of Law Number 17 Year 2008 concerning Shipping. In the case of the issuance of a sailing approval letter as set forth in case Number 37/Pid.Sus/202/PN.Smp, qualifying as a crime of abuse of authority in accordance with the theory of detournement de pouvoir because Mihtafol Arifin misused the authority given to him by issuing an Approval Letter Sailing which does not match the procedure to the KLM ship. Sinar Sumekar as mandated by Law Number 17 of 2008 concerning Shipping. In this case the article applied is Article 336 Paragraph (1) of Law Number 17 Year 2008 concerning Shipping, because Mihtafol Arifin
\end{abstract}


violates the provisions of Article 336 Paragraph (1) of Law Number 17 Year 2008 concerning Shipping. 2. In case Number 37/Pid.Sus/202/PN.Smp, defendant Mihtafol Arifin can be held accountable for his actions because a person's criminal liability depends on the mens rea element. In addition, to be able to account for his actions, the legal subject (person in charge) has fulfilled the elements: a) Responsible ability of the perpetrator, $b$ ) There is an element of error in the actions of the perpetrator, c) The existence of elements against the law and d) The absence of certain conditions forgive the actions of the offender.

Keyword: criminal liability; abuse of authority; harbourmasterer

Abstrak: Penelitian ini bertujuan: 1. Untuk mengetahui dan menganalisis kualifikasi tindak pidana penyalahgunaan wewenang di bidang pelayaran yang dilakukan oleh oknum syahbandar yang dapat dimintakan pertanggungjawaban pidana; 2. Untuk mengetahui dan menganalisis pertanggungjawaban pidana oknum syahbandar dalam tindak pidana penyalahgunaan wewenang di bidang pelayaran.

Tipe penelitian yang penulis gunakan dalam penelitian adalah penelitian normatif atau doktrinal. Teknik pengumpulan bahan hukum yang mendukung dan berkaitan dengan pemaparan penelitian ini adalah studi dokumen (studi kepustakaan).

Hasil penelitian menunjukkan bahwa:1. Dalam perkara Nomor 37/Pid.Sus/202/PN.Smp, terdakwa Mihtafol Arifin menerbitkan surat persetujuan berlayar kepada kapal KLM Sinar Sumekar yang tidak dilengkapi dengan dokumen tentang kelaikan lautan kapal sebagaimana dimaksud dalam Pasal 117 Ayat (2) Undang-Undang Nomor 17 Tahun 2008 Tentang Pelayaran, juga tidak dilengkapi dengan alat komunikasi sebagaimana dimaksud dalam Pasal 131 Ayat (2) UndangUndang Nomor 17 Tahun 2008 Tentang Pelayaran. Pada kasus penerbitan Surat Persetujuan berlayar sebagaimana yang tertuang dalam perkara Nomor 37/Pid.Sus/202/PN.Smp, terkualifikasi sebagai tindak pidana penyalahgunaan wewenang sesuai dengan teori detournement de pouvoir karena Mihtafol Arifin menyalahgunakan wewenang yang di berikan kepadanya dengan cara menerbitkan Surat Persetujuan Berlayar yang tidak sesuai prosedur kepada kapal KLM. Sinar Sumekar sebagaimana amanat Undang-Undang Nomor 17 Tahun 2008 Tentang Pelayaran. Dalam perkara ini pasal yang diterapkan adalah Pasal 336 Ayat (1) Undang-Undang Nomor 17 Tahun 2008 Tentang Pelayaran, karena Mihtafol Arifin melanggar ketentuan Pasal 336 Ayat (1) Undang-Undang Nomor 17 Tahun 2008 Tentang Pelayaran, 2. Dalam perkara Nomor 37/Pid.Sus/202/PN.Smp, terdakwa Mihtafol Arifin dapat mempertanggungjawabkan perbuatannya karena pertanggungjawaban pidana seseorang tergantung pada unsur mens rea. Selain itu, untuk dapat mempertanggungjawabkan perbuatannya, subjek hukum (oknum syahbandar) tersebut telah memenuhi unsur: a) Adanya kemampuan bertanggungjawab dari pelaku, b) Adanya unsur kesalahan dalam tindakan pelaku, c) Adanya unsur melawan hukum dan d) Tidak adanya keadaan tertentu yang memaafkan tindakan pelaku.

Kata kunci: pertanggungjawaban pidana; penyalahgunaan wewenang; syahbandar

\section{PENDAHULUAN}

Indonesia merupakan negara kepulauan dimana akses untuk menuju satu pulau dengan pulau yang lain khususnya melalui transportasi laut, hal tersebut menjadikan transportasi laut merupakan suatu kebutuhan dalam kehidupan bangsa dan persatuan bangsa sebagai

Negara kepulauan. Maka, untuk menghubungkan semua pulau di Indonesia, di perlukan 
sarana transportasi laut yang memadai baik dari segi fasilitas maupun pelayanan kegiatan kepelabuhanan.

Untuk menjamin terselenggaranya pelayaran secara tertib, aman, nyaman, dan selamat maka, di dalam Undang-Undang Nomor 17 Tahun 2008 Tentang Pelayaran di atur mengenai fungsi, tugas, tanggung jawab dan wewenang Syahbandar. Dalam Pasal 1 ayat (56) Undang-Undang Nomor 17 Tahun 2008 Tentang Pelayaran dinyatakan bahwa syahbandar adalah pejabat pemerintah di pelabuhan yang diangkat oleh Menteri dan memiliki kewenangan tertinggi untuk menjalankan dan melakukan pengawasan terhadap dipenuhinya ketentuan peraturan perundang-undangan untuk menjamin keselamatan dan keamanan pelayaran. Jadi dapat dikatakan bahwa syahbandar mempunyai otoritas tertinggi dalam melakukan pengawasan kegiatan kepelabuhanan terutama menyangkut keamanan dan keselamatan pelayaran.

Dalam melakukan kegiatan pelayaran setiap angkutan laut (kapal) memerlukan Surat Persetujuan Berlayar (SPB) yang di keluarkan oleh Syahbandar agar dapat berlayar. Surat Persetujuan Berlayar merupakan dokumen penting sebagai penentu agar sebuah kapal (angkutan laut) dapat melakukan pelayaran, sebagaimana tercantum dalam Pasal 219 Undang- Undang Nomor 17 tahun 2008 tentang Pelayaran, dinyatakan bahwa setiap kapal yang berlayar wajib memiliki Surat Persetujuan Berlayar yang dikeluarkan oleh Syahbandar dan Surat Persetujuan Berlayar tidak berlaku apabila kapal dalam waktu 24 (dua puluh empat) jam setelah persetujuan berlayar diberikan.

Penerbitan Surat Persetujuan Berlayar di berikan kepada kapal setelah perusahaan pelayaran melakukan serangkaian mekanisme pengurusan yang meliputi pengajuan permohonan penerbitan Surat Persetujuan Berlayar secara tertulis kepada syahbandar dengan melampirkan surat pernyataan kesiapan kapal (Master Sailing Declaration), dan dokumen muatan serta bukti-bukti pemenuhan kewajiban kapal lainnya. Agar dapat memperoleh Surat Persetujuan Berlayar, maka kapal yang akan berlayar harus memenuhi beberapa persyaratan, seperti syarat kelaiklautan kapal.

Keselamatan pelayaran tidak terlepas dari peran Syahbandar karena persoalan terbesar terjadinya kecelakaan pelayaran diawali dari diabaikannya prosedur. Pentingnya masalah keselamatan dan keamanan serta keseluruhan kegiatan dalam pelayaran angkutan laut merupakan tanggung jawab dalam kepelabuhanan, sebab salah satu persoalan terbesar dalam kecelakaan kapal dalam pelayaran adalah persoalan kemampuan dan keahlian seseorang menjalankan tugas kesyahbandarannya baik dalam 
melaksanakan keseluruhan tugas dalam pelabuhan serta dalam melakukan kerja sama ataupun hubungan dengan badan usaha lain yang bertugas untuk melakukan pengawasan dalam perkapalan maupun pelayaran itu sendiri.

Sekalipun telah ada peraturan yang mengatur tentang peran seorang Syahbandar dalam mengeluarkan Surat Persetujuan Berlayar. Akan tetapi, tidak jarang juga ditemui oknum syahbandar dalam menerbitkan Surat Persetujuan Berlayar yang tidak sesuai dengan mekanisme sebagaimana amanat dalam undang-undang pelayaran. Sebagai contoh Mihtafol Arifin seorang staf Adpel Kalianger dalam Perkara Nomor 37/Pid.Sus/202/PN.Smp oleh hakim divonis bersalah karena melanggar ketentuan Pasal 336 ayat 1 Undang-Undang Nomor 17 Tahun 2008 Tentang Pelayaran jo. Pasal 55 ayat 1 ke-1 KUHP, dengan menjatuhkan pidana penjara selama 4 bulan dengan masa percobaan 8 bulan.

\section{METODE PENELITIAN}

Tipe penelitian yang penulis gunakan dalam penelitian adalah penelitian normatif. Adapun pendekatan yang penulis gunakan dalam penelitian ini adalah pendekatan perundang-undangan (statute approach), pendekatan kasus (case approach) dan pendekatan konsep. Teknik pengumpulan bahan hukum yang mendukung dan berkaitan dengan pemaparan penelitian ini adalah studi dokumen (studi kepustakaan), yang dilakukan dengan cara meneliti bahan-bahan pustaka atau data sekunder yang terdiri dari bahan hukum primer, bahan hukum sekunder dan bahan hukum tertier.

\section{ANALISIS DAN PEMBAHASAN}

\section{Kualifikasi Tindak Pidana Penyalahgunaan Wewenang Di Bidang Pelayaran}

Undang-Undang Nomor 17 Tahun 2008 Tentang Pelayaran dibuat untuk mengakomodasi seluruh kepentingan yang berkaitan dengan transportasi laut dan sesuai Penjelasan Undang-undang Nomor 17 Tahun 2008 Tentang Pelayaran dimaksudkan agar "penyelenggaraan pelayaran sebagai sebuah sistem dapat memberikan sebuah manfaat sebesar-besarnya kepada seluruh rakyat, bangsa dan negara, memupuk dan mengembangkan jiwa kebaharian, dengan mengutamakan kepentingan umum, dan kelestarian lingkungan, koordinasi antara pusat dan daerah serta pertahanan keamanan negara. 
Untuk menjamin keteraturan, keamanan dan ketertiban pelayaran maka, ketentuan dalam Undang-Undang Nomor 17 Tahun 2008 Tentang Pelayaran, dimuat sanksi administrasi, sanksi perdata dan sanksi pidana. Marjono Reksodiputro, memberikan pandangan tentang sanksi, baik sanksi administrasi, sanksi perdata maupun sanksi pidana dimaksudkan untuk menegaskan pembuat undang-undang bahwa sejumlah nilai dasar sosial ingin diperkuat dan dilindungi. ${ }^{1}$

Dalam Undang-Undang Nomor 17 Tahun 2008 Tentang Pelayaran, dimuat tentang perbuatan melawan hukum atau merugikan termaksud penyalahgunaan wewenang tidak diberi sanksi administrasi dan sanksi perdata melainkan diberi sanksi pidana. Pemberian sanksi pidana dianggap sebagai sanksi yang efektif dalam menjaga ketertiban sosial. Meskipun sebenarnya Undang-Undang Nomor 17 Tahun 2008 tentang Pelayaran itu sendiri merupakan undang-undang administratif.

Wirjono Projodikoro, norma-norma atau kaidah-kaidah dalam hukum tata negara dan hukum tata usaha negara harus ditanggapi dengan sanksi administrasi, begitu pula dalam norma-norma hukum perdata harus dianggapi dengan sanksi perdata. Hanya apabila sanksi administrasi dan sanksi perdata belum mencapai tujuan meluruskan neraca kemasyarakatan maka diadakan sanksi pidana sebagai pamungkas (terakhir) atau ultimum remedium. ${ }^{2}$

Andi Hamzah memberikan pandangan mengenai undang-undang administrasi yang memiliki sanksi pidana, sebagai berikut: ${ }^{3}$

Di Indonesia semakin banyak perundang-undangan administrasi yang memuat sanksi pidana dengan pidana ancaman yang berat, sepuluh, lima belas tahun dan seumur hidup bahkan pidana mati. Undang-undang administrasi seperti narkotika, psikotropika, perbankan, dan lingkungan hidup, dan lain-lain mengandung sanksi pidana yang sangat berat, yang mestinya khusus untuk rumusan deliknya dibuat undang-undang pidana bukan administrasi. Di Belanda untuk pidana penjara yang berat itu harus dimuat dalam undang-undang pidana bukan administrasi. Undang-undang administrasi mestinya sanksinya hanya berupa kurungan dan denda.

1 Marjono Reksodiputro, Pembaharuan Hukum Pidana, Kumpulan Karangan Buku Keempat, Jakarta: Pusat Pelayanan Keadilan dan Pengabdian Hukum Univerdsitas Indonesia, 2007, hlm. 122.

2 Wirjono Projodikoro, Asas-Asas Hukum Pidana di Indonesia, Jakarta: Refika Aditama, 2008, hlm. 17.

3 Andi Hamzah, Pemberantasan Korupsi Melalui Hukum Pidana Nasional dan Hukum Internasional, Jakarta: Raja Grafindo Persada, 2007, hlm. 3. 
Andi Hamzah, kemudian menambahkan bahwa seharusnya sanksi dalam undangundang administrasi hanya berfungsi sebagai "pengawal" aturan administrasi tersebut agar ditaati orang. Itulah sebabnya maka hukum pidana dalam undang-undang administrasi disebut hukum pidana pemerintahan. ${ }^{4}$

Akan tetapi juga peneliti ingin mengetengahkan pandangan Utrecht, 5 yang menyatakan bahwa:

"Baik kepentingan yang diselenggarakan oleh peraturan hukum privat maupun kepentingan yang diselenggarakan oleh peraturan hukum publik dilindungi oleh hukum pidana, melalui suatu sanksi istimewa. Dan sanksi ini memang diperlukan karena kadang-kadang perlu diadakan tindakan pemerintah yang lebih keras, lebih keras dari sanksi-sanksi yang terdapat dalam hukum privat."

Jadi, hukum pidana selain memberi sanksi bagi pelanggar ketentuan pidana, sanksi pidana juga memberi sanksi bagi pelanggar hukum publik lainnya, yaitu sanksi administrasi.

Tujuan sanksi pidana adalah untuk menakut-nakuti orang agar jangan sampai melakukan kejahatan (preventif), serta untuk mendidik atau memperbaiki orang-orang yang sudah menandakan suka melakukan kejahatan agar menjadi orang yang baik tabiatnya (represif).

Meskipun tindak pidana penyalahgunaan wewenang hanya dikenal di dalam hukum administrasi negara. Akan tetapi, dalam Putusan Mahkamah Agung Nomor 977 K/PID/2004 dinyatakan bahwa pengertian "menyalahgunakan kewenangan" tidak ditemukan eksplisitnya dalam Hukum Pidana, maka Hukum Pidana dapat mempergunakan pengertian dan kata yang sama yang terdapat atau berasal dari cabang hukum lainnya. Hal ini berangkat dari hukum pidana mempunyai otonomi untuk memberikan pengertian yang berbeda dengan pengertian yang terdapat dalam cabang ilmu hukum lainnya, akan tetapi jika Hukum Pidana tidak menentukan lain, maka dipergunakan pengertian yang terdapat dalam cabang hukum lainnya (De Autonomie van bet Materiele Strafrecbt, yakni telah menggunakan wewenangnya untuk tujuan lain dari maksud diberikannya wewenang tersebut). Pada Putusan MA ini juga dibahas soal pengertian Detournement de pouvoir yaitu “menyalahgunakan wewenang” yang diberikan. Seseorang yang memiliki jabatan, dimana jabatan itu secara hukum diberikan

5 Uthrecht, Hukum Pidana I, Surabaya: Pustaka Tinta Mas, 1986, hlm. 65. 
"wewenang", dan wewenang itu seharusnya digunakan sebagaimana mestinya, tetapi ia menyalahgunakan wewenang tersebut.

Indriyanto Seno Adji, memberikan pengertian penyalahgunaan wewenang dengan mengutip Prof. Jean Rivero dan Prof. Waline, pengertian penyalahgunaan kewenangan dalam Hukum Administrasi dapat diartikan dalam 3 wujud yaitu6:

a. Penyalahgunaan kewenangan untuk melakukan tindakan-tindakan yang bertentangan dengan kepentingan umum atau untuk menguntungkan kepentingan pribadi, kelompok atau golongan;

b. Penyalahgunaan kewenangan dalam arti bahwa tindakan pejabat tersebut adalah benar ditujukan untuk kepentingan umum, tetapi menyimpang dari tujuan apa kewenangan tersebut diberikan oleh Undang-Undang atau peraturan-peraturan lain;

c. Penyalahgunaan kewenangan dalam arti menyalahgunakan prosedur yang seharusnya dipergunakan untuk mencapai tujuan tertentu.

Dalam perkara Nomor 37/Pid.Sus/202/PN.Smp, terdakwa Mihtafol Arifin menerbitkan Surat Persetujuan Berlayar kepada kapal KLM Sinar Sumekar yang tidak dilengkapi dengan dokumen tentang kelaiklautan kapal sebagaimana dimaksud dalam Pasal 117 Ayat (2) Undang-Undang Nomor 17 Tahun 2008 Tentang Pelayaran, juga tidak dilengkapi dengan alat komunikasi sebagaimana dimaksud dalam Pasal 131 Ayat (2) Undang-Undang Nomor 17 Tahun 2008 Tentang Pelayaran. Sehingga menurut penulis apa yang dilakukan oleh Mihtafol Arifin, terkualifikasi sebagai tindak pidana penyalahgunaan wewenang sesuai dengan teori detournement de pouvoir karena Mihtafol Arifin menyalahgunakan wewenang yang di berikan kepadanya dengan cara menerbitkan Surat Persetujuan Berlayar yang tidak sesuai prosedur kepada kapal KLM. Sinar Sumekar sebagaimana amanat Undang-Undang Nomor 17 Tahun 2008 Tentang Pelayaran. Sehingga Mihtafol Arifin dijerat dengan Pasal 336 Ayat (1) Undang-Undang Nomor 17 Tahun 2008 Tentang Pelayaran. Penerapan Pasal 336 Ayat (1) Undang-Undang Nomor 17 Tahun 2008 Tentang Pelayaran, oleh hakim kepada terdakwa Mihtafol Arifin. Sudah tepat karena pada saat melakukan tindak pidana Mihtafol Arifin merupakan pejabat yang mempunyai kompetensi untuk menerbitkan Surat Persetujuan Berlayar.

6 Benny M. Yunus, Intisari Hukum Administrasi Negara, Bandung: Alumni, 1980, hlm. 35. 
Dalam mewujudkan tindak pidana penyalahgunaan wewenang ini Mihtafol Arifin dilakukan bersama-sama dengan Sugiono (berkas tersendiri), sehingga mereka juga melanggar ketentuan pasal 55 ayat (1) ke-1 KUHP tentang penyertaan, maka dalam perumusan deliknya mengandung unsur-unsur "dengan sengaja membantu melakukan kesempatan yang di berikan kepadanya karena jabatan yang melanggar kewajiban khusus dari jabatannya yang dilakukan secara bersama-sama.

Apabila dalam suatu peristiwa pidana terdapat lebih dari 1 orang, sehingga harus dicari pertanggungjawaban dan peranan masing-masing peserta dalam peristiwa tersebut. Hubungan antar peserta dalam menyelesaikan delik tersebut, adalah:

a. bersama-sama melakukan kejahatan.

b. seorang mempunyai kehendak dan merencanakan suatu kejahatan sedangkan ia mempergunakan orang lain untuk melaksanakan tindak pidana tersebut.

c. seorang saja yang melaksanakan tindak pidana, sedangkan orang lain membantu melaksanakan.

Setidaknya ada dua persoalan pokok yang menjadi titik pangkal dalam sebuah penyertaan tindak pidana yakni pertama, mengenai diri orangnya, ialah orang-orang yang mewujudkan perbuatan pidana dan atau sikap batin yang dapat dipertimbangkan dan kedua, ditentukan sebagai terlibat atau bersangkut paut dengan tindak pidana yang diwujudkan oleh kerja sama lebih dari satu orang, sehingga ia patut dibebani tanggung jawab dan dipidana.

Mengenai tanggung jawab pidana yang dibebankan masing-masing, apakah mereka para peserta yang terlibat itu akan dipertanggungjawabkan sama atau berbeda sesuai dengan kuat tidaknya keterlibatan atau andil dari perbuatan yang mereka lakukan terhadap terwujudnya tindak pidana. ${ }^{7}$ Jadi dalam perkara penerbitan Surat Persetujuan Berlayar kepada kapal KLM. Sinar Sumekar antara Mihtafol Arifin selaku oknum Syahbandar yang menerbitkan surat persetujuan berlayar sanksinya berbeda dengan Sugiono selaku Nakhoda KLM. Sinar Sumekar yang mengajukan permohonan penerbitan Surat Persetujuan Berlayar. Dimana pertanggungjawaban pidana kepada Mihtafol Arifin berdasarkan ketentuan Pasal 336 Ayat 1 Undang-Undang Nomor 17 Tahun 2008 Tentang Pelayaran, sedangkan pertanggungjawaban pidana Sugiono berdasarkan pada ketentuan Pasal 302 Undang-Undang Nomor 17 Tahun 2008 Tentang Pelayaran (berkas tersendiri).

D. Simons, Kitab Pelajaran Hukum Pidana (judul asli: Leerboek van Het Nederlandse Strafrecht) diterjemahkan oleh P.A.F. Lamintang, Bandung: Pioner Jaya, 1992, hlm. 72. 


\section{Pertanggungjawaban Pidana Oknum Syahbandar Dalam Tindak Pidana Penyalahgunaan Wewenang Di Bidang Pelayaran}

Menurut D. Simon, ${ }^{8}$ perbuatan pidana adalah perbuatan melawan hukum dengan kesalahan yang diancam pidana yang dilakukan oleh orang yang mampu bertanggungjawab (een strafbaar getelde, onrechtmatige, met schuld verband staande handeling van een toerekeningsvatbaar persoon). Berdasarkan pengertian di atas, unsurunsur perbuatan pidana yaitu:

a. Perbuatan manusia (positief atau negatief);

b. Diancam dengan pidana (strafbaar gesteld);

c. Melawan hukum (onrechtmatig);

d. Dilakukan dengan kesalahan (met schuld in verband staand);

e. Oleh orang yang mampu bertanggungjawab (toerekeningsvatbaar persoon).

Perbuatan pidana terdiri dari 2 (dua) unsur yaitu unsur objektif dan unsur subjektif.

a. Unsur objektif terdiri dari:

1) Perbuatan orang;

2) Akibat yang kelihatan dari perbuatan itu;

3) Mungkin ada keadaan tertentu yang menyertai perbuatan itu (ex. Openbaar).

b. Adapun unsur subjektifnya terdiri atas:

1) Orang yang mampu bertanggungjawab

2) Adanya kesalahan (dolus/culpa), dapat berupa akibat dari perbuatan.

Dari semua perbuatan tersebut, tidak semua perbuatan yang memenuhi rumusan delik harus dipidana. Karena syarat untuk dipidananya seseorang yaitu harus ada kesalahan/mampu dipertanggungjawabkan. Dalam hal ini berlaku asas tiada pidana tanpa kesalahan/Keine strafe ohne schuld/Geen Straf Zonder Schuld/Nulla poena sine culpa/Actus non facit reum nisi mens sit rea.

Salah satu unsur subjektif dari perbuatan pidana adalah orang yang mampu bertanggung jawab dan dilakukan dengan kesalahan.

Dalam Kitab Undang-Undang Hukum Pidana (Crimineel Wetboek) Tahun 1809 dicantumkan: "Sengaja ialah kemauan untuk melakukan atau tidak melakukan perbuatan-

8 Ibid, hlm. 44. 
perbuatan yang dilarang atau diperintahkan oleh undang-undang". Adapun pembagian jenis sengaja yang secara tradisional di bagi tiga jenis, yaitu: ${ }^{9}$

a. Sengaja sebagai maksud (Opzet als oogemark);

b. Sengaja dengan kesadaran tentang kepastian (Opzet met bewustheid van zekerheid of noodzakelijkheid);

c. Sengaja dengan kesadaran kemungkinan sekali terjadi (Opzet met waarschlijkheidbewustzijn).

Bentuk lain dari kesalahan selain kesengajaan yaitu kelalaian atau kealpaan. Undang-undang tidak memberikan definisi apakah kelalaian atau kealpaan itu, hanya memori penjelasan (M.v.T) mengatakan bahwa kelalaian atau kealpaan (culpa) terletak antar sengaja dan kebetulan, bagaimanapun juga culpa dipandang lebih ringan dibanding dengan sengaja, oleh karena itu menurut Hazewinkel-Suringa mengatakan bahwa delik culpa itu merupakan delik semu (quasideliet) sehingga diadakan pengurangan pidana. ${ }^{10}$

Dalam perspektif teori, culpa dibagi menjadi dua11, yaitu: pertama culpa yang disadari, ialah pembuat sama sekali tidak menghendaki akibat/keadaan yang berhubungan dengan itu, ia melakukan perbuatan dengan kesadaran dapat menghindarinya, kedua culpa yang tidak disadari, ialah pelaku tidak memiliki dugaan atau pikiran bahwa perbuatannya dapat menimbulkan akibat tertentu yang dilarang hukum.

Sedangkan delik culpa ini dalam rumusan undang-undang ada dua (2) macam, yaitu delik kelalaian yang menimbulkan akibat (culpose gevolgsmisdrijven) dan yang tidak menimbulkan akibat, tapi yang diancam dengan pidana ialah perbuatan ketidak hatihatian itu sendiri. Perbedaan antara keduanya sangat mudah dipahami yaitu kelalaian yang menimbulkan akibat dengan terjadinya akibat itu maka diciptalah delik kelalaian, sedangkan bagi yang tidak perlu menimbulkan akibat dengan kelalaian atau kurang kehati-hatian itu sendiri sudah diancam dengan pidana.

Syarat-syarat elemen yang harus ada dalam delik kealpaan yaitu menurut Van Hamel, yaitu 12

a. Tidak mengadakan praduga-praduga sebagaimana diharuskan oleh hukum, adapun hal ini menunjuk kepada:

\footnotetext{
9 Moeljatno, Op. Cit, , hlm. 174-177.

10 Andi Hamzah, Bunga Rampai Hukum Pidana dan Acara Pidana, Jakarta: Ghalia Indonesia, 1986, hlm. 125.

11 Moeljatno, Op. Cit, hlm. 210.

12 Bambang Poernomo, Asas-Asas Hukum Pidana, Yogyakarta: Ghalia Indonesia, 1983, hlm. 174.
} 
1) Terdakwa berpikir bahwa akibat tidak akan terjadi karena perbuatannya, padahal pandangan itu kemudian tidak benar. Kekeliruan terletak pada salah pikir atau pandang yang seharusnya disingkirkan.

2) Terdakwa sama sekali tidak punya pikiran bahwa akibat yang dilarang mungkin timbul karena perbuatannya. Kekeliruan terletak pada tidak mempunyai pikiran sama sekali bahwa akibat mungkin akan timbul hal mana sikap berbahaya.

b. Tidak mengadakan penghati-hatian sebagaimana diharuskan oleh hukum, mengenai hal ini menunjuk pada tidak mengadakan penelitian kebijaksanaan, kemahiran atau usaha pencegah yang ternyata dalam keadaan yang tertentu atau dalam caranya melakukan perbuatan.

Orang yang mampu bertanggungjawab merupakan subjek hukum. Subyek hukum adalah orang yang dapat dipertanggungjawabkan sebagai pelaku tindak pidana. Subjek hukum dalam Pasal 336 ayat (1) Undang-undang Nomor 17 Tahun 2008 tentang pelayaran menggunakan istilah setiap pejabat.

Dalam perkara Nomor 37/Pid.Sus/202/PN.Smp yang menjadi subjek hukumnya setiap pejabat, yakni Mihtafol Arifin seorang staf Adpel Kalianger. Sebagai subyek hukum, Mihtafol Arifin. dalam keadaan sehat fisik dan mentalnya, hal ini terlihat dari tingkah lakunya, cara dan bertutur kata serta penalarannya dalam mengikuti jalannya sidang. Sehingga ia mampu dan dapat dimintakan pertanggungjawaban atas perbuatannya. Selain itu, Mihtafol Arifin sebagai terdakwa dalam kasus penerbitan Surat Persetujuan Berlayar dalam perkara Nomor 37/Pid.Sus/202/PN.Smp dapat mempertanggungjawabkan perbuatannya karena tidak terdapat hal-hal yang dapat menghapus pertanggungjawaban pidana baik alasan pemaaf maupun alasan pembenar sebagaimana yang diatur dalam Pasal 44, 48, 49, 50, 51 KUHP.

Dari pertimbangan hakim, bentuk kesalahan yang dilakukan oleh terdakwa jika dikualifikasikan adalah sengaja. Dalam hal ini, sengaja dapat berarti sengaja untuk berbuat sesuatu dan sengaja untuk tidak berbuat sesuatu (lalai) yang harusnya dilakukan. Jika bentuk kesalahan yang dilakukan oleh terdakwa dikualifikasikan, maka kesalahannya tergolong sengaja dalam hal tidak melakukan pengecekan (lalai). Mihtafol Arifin, dalam menerbitkan surat persetujuan berlayar tidak melakukan pemeriksaan langsung terhadap dokumen kapal (dokumen kelaiklautan kapal dan dokumen alat komunikasi) yang diajukan oleh Sugiono selaku Nakhoda KLM. Sinar Sumekar. 
Untuk dapat mempertanggungjawabkan perbuatannya, subjek hukum (oknum syahbandar) tersebut harus memenuhi unsur; pertama, adanya kemampuan bertanggungjawab dari pelaku, kedua, dannya unsur kesalahan dalam tindakan pelaku, ketiga, adanya unsur melawan hukum, dan keempat, tidak adanya keadaan tertentu yang memaafkan tindakan pelaku.

Dari keempat unsur tersebut, ke semua unsurnya telah terpenuhi pada perkara Nomor 37/Pid.Sus/202/PN.Smp dengan terdakwa Mihtafol Arifin. Sehingga, dapat atau tidaknya perbuatan terdakwa Mihtafol Arifin dipertanggungjawabkan perbuatannya telah jelas. Berdasar pada penerapan bentuk pertanggungjawaban pidana yaitu based of foulth. Dimana, pertanggungjawaban pidana seseorang tergantung pada unsur mens rea. Maka pada perkara ini Mihtafol Arifin dapat mempertanggungjawabkan perbuatannya.

\section{KESIMPULAN}

1. Dalam perkara Nomor 37/Pid.Sus/202/PN.Smp, terdakwa Mihtafol Arifin menerbitkan Surat Persetujuan Berlayar kepada kapal KLM Sinar Sumekar yang tidak dilengkapi dengan dokumen tentang kelaiklautan kapal sebagaimana dimaksud dalam Pasal 117 Ayat (2) Undang-Undang Nomor 17 Tahun 2008 Tentang Pelayaran, juga tidak dilengkapi dengan alat komunikasi sebagaimana dimaksud dalam Pasal 131 Ayat (2) Undang-Undang Nomor 17 Tahun 2008 Tentang Pelayaran. Pada kasus penerbitan Surat Persetujuan berlayar sebagaimana yang tertuang dalam perkara Nomor 37/Pid.Sus/202/PN.Smp, terkualifikasi sebagai tindak pidana penyalahgunaan wewenang sesuai dengan teori detournement de pouvoir karena Mihtafol Arifin menyalahgunakan wewenang yang di berikan kepadanya dengan cara menerbitkan Surat Persetujuan Berlayar yang tidak sesuai prosedur kepada kapal KLM. Sinar Sumekar sebagaimana amanat Undang-Undang Nomor 17 Tahun 2008 Tentang Pelayaran. Dalam perkara ini pasal yang diterapkan adalah Pasal 336 Ayat (1) Undang-Undang Nomor 17 Tahun 2008 Tentang Pelayaran, karena Mihtafol Arifin melanggar ketentuan Pasal 336 Ayat (1) Undang-Undang Nomor 17 Tahun 2008 Tentang Pelayaran.

2. Dalam perkara Nomor 37/Pid.Sus/202/PN.Smp, terdakwa Mihtafol Arifin dapat mempertanggungjawabkan perbuatannya karena pertanggungjawaban pidana seseorang tergantung pada unsur mens rea. Selain itu, untuk dapat 
mempertanggungjawabkan perbuatannya, subjek hukum (oknum syahbandar) tersebut telah memenuhi unsur pertama, kemampuan bertanggungjawab, kedua, adanya unsur kesalahan, ketiga, adanya unsur melawan hukum, serta keempat, tidak adanya alasan pemaaf.

\section{Daftar Pustaka}

\section{Buku}

Hamzah, Andi, Bunga Rampai Hukum Pidana dan Acara Pidana, Jakarta: Ghalia Indonesia, 1986.

Pemberantasan Korupsi Melalui Hukum Pidana Nasional Dan Hukum Internasional, Jakarta: Raja Grafindo Persada, 2007.

Moeljatno, Asas-Asas Hukum Pidana, Cetakan Ke-9, Jakarta: Rineka Cipta, 2015.

Poernomo, Bambang, Asas-Asas Hukum Pidana, Yogyakarta: Ghalia Indonesia, 1983.

Projodikoro, Wirjono, Asas-Asas Hukum Pidana Di Indonesia, Jakarta: Refika Aditama, 2008.

Reksodiputro, Marjono, Pembaharuan Hukum Pidana, Kumpulan Karangan Buku Keempat, Jakarta: Pusat Pelayanan Keadilan Dan Pengabdian Hukum Univerdsitas Indonesia, 2007.

Simons, D., Kitab Pelajaran Hukum Pidana (judul asli: Leerboek van Het Nederlandse Strafrecht) diterjemahkan oleh P.A.F. Lamintang, Bandung: Pioner Jaya, 1992.

Uthrecht, E., Hukum Pidana I, Surabaya: Pustaka Tinta Mas, 1986.

Yunus, Benny M., Intisari Hukum Administrasi Negara, Bandung: Alumni, 1980.

\section{Perundang-Undangan}

Kitab Undang-Undang Hukum Pidana

Undang-Undang Nomor 17 Tahun 2008 tentang Pelayaran (Lembaran Negara Republik Indonesia Tahun 2008 Nomor 64, Tambahan Lembaran Negara Republik Indonesia Nomor 4849) 